\title{
DIE NOODSAAKLIKHEID VAN ONDERRIG- ONTWIKKELING AAN DIE UNIVERSITEIT
}

\author{
S.J.P. du Plessis
}

Direkteur: Buro vir Universiteilsonderwys, PU vir CHO

\begin{abstract}
As a result of a shorlage of skilled manpower, the rapid increase in knowledge and technological development, personnel development has become an issue of great and urgent necessity.

In this article the author looks at the necessity of teaching development as an important component of the development and promotion of lecturing at the university, and comes to the conclusion that lecturers at tertiary (university) level need to be made cognizant of recent developments in the techniques of tertiary teaching so that teaching can be as effective as possible in an effort to render more effective service to the community served by the uninersity.
\end{abstract}

\section{UITGANGSPUNTE EN BEGRIPSBEPALING}

In hierdie tyd van geweldige kennsitoename en tegnologiese ontwikkelings het mannekragont wikkeling en indiensopleiding noodsaaklik en vanselfsprekend geword. Geen persoon kan vir eens en vir altyd opgelei wees nie. Sommige instansies het personeel in diens wat personeelontwikkeling as taak het terwyl ander hulp van buite inroep om hierdie taak te behartig. Omstandighede het universiteite ook verplig om hieraan aandag te gee en die akademiese personeellede, die dosente, word nou in hierdie proses betrek.

Dosentontwikkeling aan die universiteit het ten doel dat die dosent:

* 'n verbondenheid sal verkry en behou aan die doclstellings aan die universiteit;

- die universiteit en die studente se behoeftes sal ken en verstaan;

- tydens sy dienstydperk die kundigheid sal verwerf en gebruik om vaardig en doelgerig te onderrig en te lei sodat die st udente maksimaal met insig sal lecr;

* die wetenskap sal bevorder deur navorsing;

$48(4) 1983$ 
* in gemeenskapsdiens betrokke sal raak; en

- die vaardigheid sal ont wikkel om by te dra tot die gladde verloop van die universiteit se bestuur en administrasie (Behr, 1981:40).

Dosenteontwikkeling is dus die skepping van ontwikkelingsgeleenthede vir die dosent oor die hele spektrum van sy aktiwiteite.

Waar daar sprake is van ont wikkeling moet daar groei en vooruitgang wees. Dit impliseer geensins dat die bestaande verkeerd is nie maar daar moet voortgebou word en geheroriënteer word. Dosenteontwikkeling moet dosente help om bestaande take so suksesvol moontlik uit te voer maar moet ook help om hulle voor te berei vir nuwe asook groter verantwoordelikhede en pligte om sodoende ook groter werksbevrediging te smaak.

Dosenteontwikkeling is ' $\mathrm{n}$ breër begrip as onderrigontwikkeling en sluit onderrigontwikkeling in. Onderrigontwikkeling in die enger betekenis het hoofsaaklik betrekking op die uitvoering van die taak van die dosent as leermeester. Onderrigont wikkeling het ten doel om 'n suksesvolle leeraktiwiteit as die resultaat van doeltreflende onderrig te skep.

Opvoeding of leiding vertoon radikaal anders by volwassenes as by kinders en dit is vanselfsprekend dat die studie van volwasse opvoeding aanleiding sal gee tot die totstandkoming van 'n wesenlik ander opvoedkundige struktuur waarvan die doel nie net behoorlike volwassenheid is nie maar ook verdiepende volwassenheid (Strydom, 1980:30).

'n Persoon wat opgelei is as pedagoog is dus nie meteens 'n andragoog nie. In die praktyk beteken dit ook dat 'n professioneel-opgeleide onderwyser nie vanselfsprekend opgewasse is vir die onderrigtaak op universiteit nie.

Andragogiek het vandag ' $n$ buitengewone belangrike deelwetenskap geword as gevolg van die noodsaaklikheid van heropleiding, indiensopleiding en voortdurende onderwys. Dit is opvallend dat 'n deelwetenskap wat in die tyd van die Griekse wysgere reeds prominensie geniet het vir eeue lank in die vergetelheid weg gesink het en nou sterk na vore tree. In ons land waar die nie-formele onderwys in die toekoms 'n belangriker rol gaan speel, sal meer aandag aan die Andragogiek geskenk moet word. Daar is baie persone wat as begeleiers van volwassenes moet optree wat nie oor die andragogiese agtergrond daarvoor beskik nie. Dit is ook opvallend dat die andragogiek selde in kursusse aan Suid-Afrikaanse universiteite figureer. Baie dosente 


\section{Die noodsaaklikheid van}

aan Suid-Afrikaanse universiteite beskik oor geen opleiding vir hulle onderrig-en vormingstaak nie. Aan die universiteit word die student as jong volwassene in ' $n$ bepaalde rigting gelei. Nie net kognitiewe doelstellings moet bereik word nie maar ook die affektiewe; hoof en hart.

Vorming en rigtinggewing veronderstel dus dadelik dat die onderwys nie neutraal en die wetenskapsbeoefening nie neutraal sal wees nie. Neutrale onderwys en neutrale wetenskapsbeoefening plaas alles wat rigtinggewend is in die mens se lewe, dit wat die lewe sinvol vir hom mak buite die grense van sekere wete. Die dosent en wetenskaplike se gevoelens, waardes en gesindhede kan nie buite sy wetenskaplike arbeidsveld gehou word nie. Kliniese ontleding en analise, wat die neutrale wetenskap bied, vra ook doelwitte, en doelwitte veronderstel waardes en ideale (Schutte, 1979:22). Die dosent, die andragoog, kan nie in naam van objektiwiteit die rug keer op die beantwoording van vrae na waardes en doelwitte nie. In onderrigontwikkeling word doelwitgerigte onderrig beklemtoon met die gepaardgaande vrae na waardes en norme, na uitgangspunte.

\section{DIE NOODSAAKLIKHEID VAN ONDERRIGONTWIKKELING}

\subsection{Die eise wat aan die universileit gestel word}

Die universiteit het deur die eeue 'n redelik geïsolcerde bestaan gevoer. 'n Vereenvoudigde beeld van 'n inrigting met suiwer akademiese ideale wat rustig en geïsoleerd van die dinamika van die lewe voortbestan, het posgevat. Volgens die ou en gerespektcerde standpunt is die universiteitsprofessor 'n akademikus wat sy lewe aan studie en navorsing wy en dit lei hom tot ontdekkings en insigte wat hy deel met die gemeenskap van akademici deur boeke, artikels en lesings. Enigeen wat bckend wil raak met die professor se werk moet sy boeke en artikels lees en sy lesings bywoon. Wat die student leer is sy eie saak. Die professor het sy werk gedoen en om te praat van onderrigverbetering kan eintlik net beteken dat hy meer lesings moet gee of meer moet skryf.

Veral sedert die Tweede Wêreldoorlog het groot veranderings op die onderriggebied ingetree. Tot op daardie stadium was die universiteit en dosente in die posisie dat hulle as't ware 'n monopolie gehad het oor hoë-vlakkennis en oor hoe kennis oorgedra word. Tans kan daar egter gepraat word van dic kennis-industrie en ander instansies wat nie skole of universiteite is nie en mense wat nie noodwendig opvoeders is nie, stel kennis beskikbaar. Dit is opvallend dat oral oor dic wêreld in onderrigont wikkeling 
aan die universiteit lae-profielstrategieë gevolg word, miskien omdat in die buitewêreld tot onlangs nog die gedagte bestaan het dat universiteitsonderwys net goed kon wees vanweë die status wat akademici geniet het. 'n Nuwe geslag mense wat bekend is met die universiteit en voel hulle bekwaam om onderrig op universiteit baie deeglik en krities te beskou. Werkgewers wat in al groter mate van die produkte van dic universiteit in diens neem, vra ook vrae na die effektiwiteit van die opleiding. Baie dosente het hulle onderrigstyl verkry deur dit wat hulleself twee of drie dekades gelede ten opsigte van die onderrig op universiteit ervaar het. So 'n posisie is nie meer houdbaar nie.

Naas die gemeenskap het ook die owerhede met nuwe oë na die universiteit begin kyk.

In die ontwikkelde lande vra die owerheid wie vir hierdie duur soort opleiding in aanmerking behoort te kom en wat die owerheid se verantwoordelikheid ten opsigte van die universiteitsonderrig van die duisende studente is.

In die onderontwikkelde en ontwikkelende lande is die gemeenskap en die owerheid se belangstelling meer daarop gerig dat onderwysgeriewe geskep word wat ontwikkeling kan versnel. Universiteite word ook as prestige inrigtings gesien. Met die onafhanklikwording van Afrikastate is ontsaglike finansiële koste aangegaan vir die vestiging van universiteite. Die universiteit moes leiding gee op die weg van modernisering en moes ook geskoolde mannekrag lewer ten einde werklike onafhanklikheid te bereik (Leistner, 1982:7). Baie van hierdie universiteite is egter, net soos die Suid-Afrikaanse universiteitc, op die Europese universitĉre tradisie geskoei. Nodeloos om te sê dat daar nie aan die verwagtings van die onderont wikkelde lande voldoen is nie. 'n Blote universiteitsgraad verseker nie ekonomiese vooruitgang en groei nie en universiteitsonderwys kan nie in isolasie bestaan nie maar moet gesteun word deur primêre, sekondêre en tegniese onderwys.

Die skuld vir die mislukking is egter in baie gevalle voor die deur van die universiteit en van die dosent en sy onderrig gelê. Die tradisionele vormingsideaal van die Europese universiteit het ook op ons primêre en sekondêre onderwys die merk gelaat. In die RGN-verslag oor onderwysvoorsiening in die RSA word gewag gemaak van die akademiese waardesisteem van ons onderwys. Nagenoeg $80 \%$ van alle blanke matriekleerlinge en $99 \%$ van alle swart matriekleerlinge kwalifiseer in die sogenaamde akademiese matriekkursus. Die klassieke en kultuurvakke wat vir baie eeue die kern 


\section{Die noodsaaklikheid van}

gevorm het van die Europese opvoedkundige stelsels en in ons onderwys oorgeneem is, is nou skerp onder die soeklig en dit kan verwag word dat in die nabye toekoms verandering gaan intree soos deur die RGN-verslag oor onderwysvoorsiening in die RSA aanbeveel.

Die akademiese waardesisteem van ons onderwysstelsel het in 'n sekere sin universiteite bevoordeel omdat baie leerlinge na matriek eintlik verplig is om na die universiteit te gaan. Hierdie toestand is vinnig besig om te verander en die universiteit sal in 'n sekere sin in kompetisie tree met ander tersiêre onderwysinrigtings. Waar die universiteit vrocër in ons land feitlik alleenheerskappy gevoer het wat tersiêre onderwys betref, breek 'n typerk aan waar die technikons baie sterk op die voorgrond sal tree en sal die universiteit baie deeglik moet besin oor onderwysdoelstellings.

In baie gevalle word die student se hele beroepsvoorbereiding deur die universiteit gedoen en dit spreck vanself dat die dosent by die toegepaste element in sy onderrig moet uitkom. Dit plaas'n groot verantwoordelikheid op die dosent. Skakeling moet behou word met die arbeidsmark om sodoende behoeftes vas te stel maar die dosent het ook die verpligting om in sy leerstofseleksie en sy hele kurrikulumbeplanning die wese en taak van die universiteit te verstaan en in aanmerking te neem. As die universiteit toegee aan eise om pasklaar produkte wat heeltemal beroeps-en praktykgereed is af te lewer, moet hy weet dat hy die universitêre doelstellings nie verwesenlik het nie. Dat die universiteit al in 'n mate toegegee het aan hierdie eise spreek uit die groot aantal nuwe grade en diplomas wat reeds ingestel is. Ten opsigte van die blanke deel van ons bevolking het die sogenaamde graadsiekte ook reeds kop uitgesteek. Die individu se kanse op die arbeidsmark is afhanklik van die verworwe grade en diplomas en die persoon wat oor die hoër opvoedkundige kwalifikasie beskik word eerder in 'n betrekking aangestel of kry makliker bevordering terwyl in baie gevalle nie werklik na die produktiwiteit of uitsette gekyk word nie. Hierdie verskynsel plaas ook druk op die universiteit en op die dosent. Studente kom na die universiteit bloot om 'n kwalifikasie te verwerf en dikwels kom persone ook verder studeer met valse motiewe. Die doktorsgraad is eerstens 'n graad wat daarvan getuig dat die houer daarvan navorsing kan doen. Vir baie getuig dit egter in die eerste plek van hoě intellektuele vermoë en word in baie gevalle gepoog om die navorsingsgraad te verwerf om die status daarvan.

Opvoedkundige inflasie, dit is waar steeds hoër opvoedkundige kwalifikasies vereis word vir bepaalde betrekkings, word ook ten opsigte van die blanke 


\section{S.J.P. du Plessis}

deel van ons bevolking bemerk. In baie gevalle is dit meer uit mode as uit noodsaaklikheid of getuig daarvan dat die opleiding wat wel ontvang is nie geskik is vir die doel nie. Ook dit plaas 'n groot verant woordclikheid en druk op die dosent en sy onderrigbeplanning.

Die universiteit en universiteitsonderwys is in 'n sekere mate in 'n krisis. Die wese van die universiteit het verander. Die tradisionele universiteit met sy idee van die universitas magistrorum et scholarum, dit is, die gemeenskap van leermesters en leerlinge, waar die leergierige student die leermeester opsock om aan sy voete die waarheid te soek en te vind en waar die samehang van die wetenskap, die stadium generale, gesoek word, verskil grootliks van die universiteit van vandag. In 'n ondersoek wat in 1979 aan een van ons residensiële universiteite uitgevoer is het nagenoeg $75 \%$ van die nuwelingeerstejaars gesê dat beroepsbekwaming dic belangrikste rede is waarom hulle universiteit toe gekom het. Minder as $5 \%$ van die studente het as belangrikste rede aangegee dat hulle kom studecr het om die vormende waarde van gelcerdheid te verkry (Van der Merwe, 1980:18). Die universiteit, en dus die dosent, moet hom nie laat verlei nic. 'n Graad moet 'n student in staat stel om vir die res van sy lewe' $n$ student te bly en dit moet nie net 'n verklaring wees dat hierdie 'n beroepsafgerigte persoon is nie. Daar moet 'n gesonde balans tussen gespesialiseerdc opleiding en algemene breè opleiding met 'n wye gebied van toepassing wees. Die Westerse ekonomieë gaan juis gebuk onder die finansiële juk van oorgespesialiseerde werkers (Viljoen, 1983:6).

Opsommend kan gesê word dat die universiteit wel outonoom is en dat dosente akademiese vryheid geniet, maar hulle kan tog die eise van die gemeenskap en die Staat nie vryspring nie. Soos alle ander menslike instellings is die universiteit ook met talle bande van gemeenskaplike belang en verant woordelikheid aan ander instellings verbonde (Preller en Strydom, 1978:20). Geen menslike instelling is volkome outonoom nie en sy vryheid is relatief. Die staat, die ouers, professionele liggame, die wetenskappe, en die gemeenskap as geheel stel eise aan die universiteit. Dit is die dosent wat sal moet sorg dat 'n steeds gesonde balans gehandhaaf word. Dit is hy wat uiteindelik tog inhoud aan die kurrikulum gee en wat die toon en aard van die leerinhoud bepaal. Kurrikulering het in ons dag 'n gespesialiseerde taak geword en onderrigontwikkeling kan vir die dosent hier van groot waarde wees.

\subsection{Demokratisering van die onderwys}

Een van die groot onderrigprobleme aan die universiteit is in die groot getalle 


\section{Die noodsaaklikheid van}

studente geleë en die vinnige toename in studentegetalle. Waar daar in 1950 18000 studente op die universiteitskampusse van die RSA was, het dit in 1960 gestyg tot 30000 en tans is daar op die blanke residensiële universiteite al meer as 80000 studente. Sedert 1918 het die studente tot sestigvoudig tocgencem. Die toename in studentegetalle het ook 'n toename in die heterogenitcit van die universiteitsbevolking teweeggebring. Waar daar in $195730 \%$ van 'n betrokke ouderdomsgrocp Standerd 10 geslaag het, verwerf nagenoeg 35\% tans universiteitstoelating. In 1978 het nagenoeg dieselfde persentasie van die betrokke ouderdomsgroep as eerstejaarstudente by die universiteit ingeskry $f$ as wat in 1957 Standerd 10 geslaag het.

In figuur 1 word gegewens aangegee van blanke matrikulante en eerstejaarstudente in die Republiek van Suid-Afrika aan residensiële universiteite.

Figuur 1.

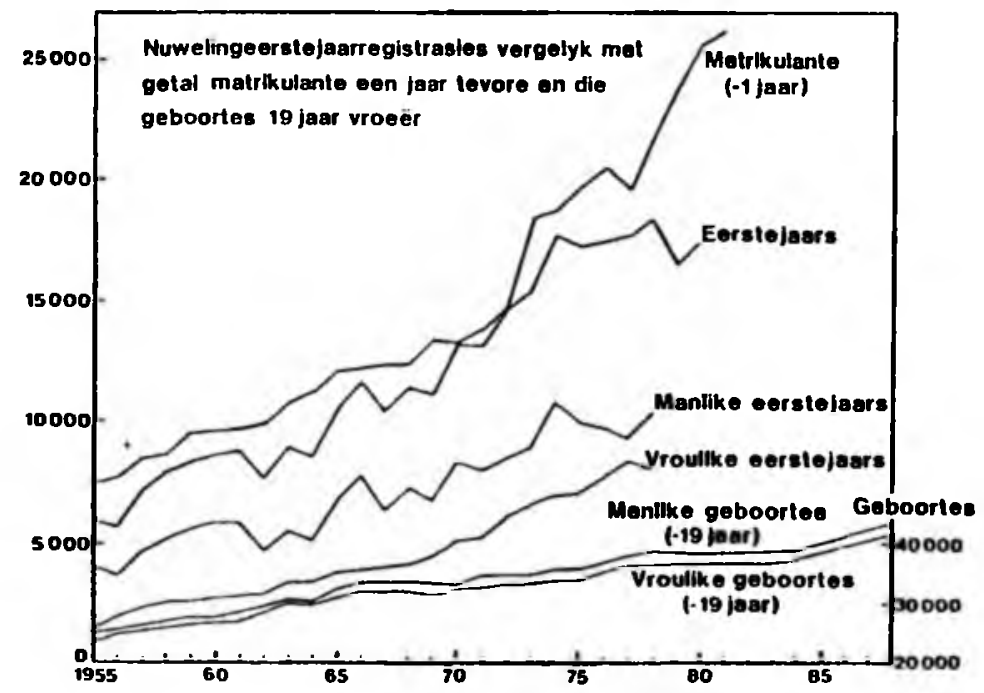

(ERENS EN LOUW, 1978:37; cn STLYN, VEN'TER \& LOUW, 1983:19.)

Soos gesien kan word het die getal matrikulante en eerstejaarstudente vanal 1955 tot ongeveer 1978 geweldig vinnig gestyg en het feitlik alle studente wat matrikulasievrystelling verwerf het na die universitcit gegaan. Dit is nie in verhouding tol die geboortetempo soos op die figuur aangedui is nie. 


\section{S.J.P. du Plessis}

Dit wil dus voorkom asof feitlik alle blanke skoliere wat enigsins die verstandelike vermoë het wel later by die universiteit inskryf. Slegs nagenoeg $\mathbf{4 0 \%}$ van die eerstejaarstudente het matriek in die eersteklas geslaag.

Die getal persone uit die verskillende hoofhevolkingsgroepe wat matrikuleer word in tabel 1 weergegee.

Tabel 1

GETAL PERSONE UIT HOOFBEVOLKINGSGROEPE WAT MATRIKULEER

$\begin{array}{rrccr} & \text { BLANK } & \text { KLEURLING } & \text { INDIËR } & \text { SWART } \\ 1970 & 14189 & 459 & 410 & 1104 \\ 1980 & 26149 & 1670 & 2055 & 6901 \\ 1990 & 29824 & 2253 & 3704 & 14024 \\ 2000 & 24604 & 2415 & 3953 & 20242\end{array}$

(STEYN et al, 1983:18).

Uit die tabel blyk dat ten opsigte van die blankes wat matrikuleer daar reeds byna ' $n$ versadigingspunt bereik is en dat daar na die einde van hierdie eeu toe selfs'n daling sal wees vanweë die dalende geboortesyfer. Wat opval is die geweldige toename en verwagte toename in matrikulantc onder die swartes.

Die verhouding tussen die blanke nuwelingeerstejaarstudente aan residensiële universiteite tot die getal wat die jaar tevore gematrikuleer het en die totale getal blanke geboortes 19 jaar vroeër word in tabel 2 weergegee.

Tabel 2

GEGEWENS T.O.V. BLANKE NUWELINGEERSTEJAARS

$\begin{array}{lccccc}\text { JAAR } & \text { 1* } & 2 * * & 3 * * & \begin{array}{c}1: 2 \\ (\%)\end{array} & \begin{array}{c}1: 3 \\ (\%)\end{array} \\ 1969 & 11175 & 13545 & 65492 & 81 & 17 \\ 1972 & 14743 & 15267 & 69049 & 96 & 21 \\ 1975 & 17306 & 20601 & 70469 & 84 & 24 \\ 1978 & 19445 & 22253 & 76016 & 87 & 25 \\ 1981 & 17263 & 26149 & 76581 & 66 & 23\end{array}$

1* - Aantal nuwelingeerstejaarstudente

2** - Aantal gematrikulecrdes een jaar tevore

3*** - Aantal geboortes 19 jaar tevore

(STEYN et al., 1983:19). 


\section{Die noodsaaklikheid van}

Uit tabel 2 blyk dat die getal gematrikulcerdes steeds toencem ten spyte daarvan dat die totale aantal geboortes 19 jaar tevore reeds gestabiliseer het. Uit kolom I blyk dat die getal nuwelingeerstejaars afgeplat het ten spyte van die toename in aantal gematrikuleerdes. Uit die laaste kolom blyk dat die verhouding tussen die totale aantal nuwelingecrstejaars tot die totale getal geboortes 19 jaar tevore op ongeveer $23 \%$ gestabiliseer het. Hierdie ongeveer een kwart van die ouderdomsgrocp wat as eerstejaars by die universiteit inskry plaas, soos reeds genoem, 'n swaar las op dic skouers van die dosent omdat hy nie meer met so'n homogene, uitgesoekte groep studente werk nie en dus meer pogings moet aanwend om die onderrig te individualiseer. Studente moet tocgelaat word om teen eie tempo te vorder en die leergeleenthede moet so ingekleur word. Ook moet meer voorsiening gemaak word vir diagnose en remediërende werk. Dit vereis ook bykomende vaardighede van die dosent. Studiemetodevoorligting kan ook 'n belangrike rol spcel om die heterogene groep studente teen min of meer dieselfde pas te laat vorder.

Met die demokratisering van die onderwys het die getalle studente in klasse geweldig toegeneem en in sommige klasse sit daar etlike honderde studente. Hier sou nie eers die beproefde universiteitsonderrigmetode, naamlik die Sokratiese metode van vraag en antwoord, wat uit ' $n$ tyd voor die geboorte van Christus dateer, gebruik kan word nie. Die versoeking is dus groot om formele lesings te gee waar daar net eenrigting kommunikasie is en feitlik geen individualisering nie. Die gesonde onderrigbeginsel van vinnige terugvoer wat lei tot versterking van leer ly in die proses ook daaronder. Die universiteit het nie 'n goeie rekord wat betref onderrig aan groot groepe studente nie en onderrigassistente kan help om die toestand te verbeter.

Met die beroepsgerigte opleiding wat gegee word het baie eerstejaarkursusse verander in sogenaamde dienskursusse. Studente het die betrokkc kursus nodig om uiteindelik dic beroepsgerigte graad te verwef maar stel nie werklik in die vak as sodanig belang nie. Die dosent het die probleem dat hy voor 'n klas van etlike honderde staan in die eerstejaar maar dat die getal studente in die tweede- en derdejaar op sy vingers getel kan word. So 'n dosent moet hom dus ingrawe om effektief onderrig te gee aan 'n groot groep redelik ongemotivecrde studente.

'n Interessante verskynsel is dat alhoewel daar die afgelope jare nie meer 'n styging in die totale aantal nuwelingecrstejaarstudente was nie die totale getal aan universiteite vir blankes toegeneem het. Die rede hiervour is daarin 


\section{S.J.P. du Plessis}

geleë dat studente oor die algemeen langer kursusse volg en dat ook ouer persone vir universiteitstudie inskryf. Verder begin dit ook voorkom dat studente wat reeds oor universiteitskwalifikasies beskik weer terugkom om hulle verder te bekwaam of om heeltemal 'n nuwe studierigting in te slaan. Die verandering in eienskappe van die studentebevolking noop ook weer 'n nuwe benadering tot die onderrig.

Dic relatief hoë persentasie nagraadse studente wat huidiglik aan universiteite studeer plaas ook 'n besondere las op die skouers van die dosent en stel besonderse eise aan sy onderrig. Daar is in die literatuur al meer sprake van kwaternêre onderrig wat onderskei moet word van tersiêre of dan voorgraadse onderrig, wat in ons tyd eintlik 'n soort van volksonderwys geword het.

Die dosent moet ook onderlê word om groot groepe nagraadse studente te hantcer.

\subsection{Litsakkoers van studente}

Die nagenoeg een derde van die studente wat as eerstejaars by universiteit inskryf en nie later daarin slaag om 'n graad of diploma te verwerl' nie, ontstcl. Heelwat mannekrag gaan verlore en die sellbeeld van die studente wat druip lei ook claaronder. Alhoewel daar die afgelope jare 'n merkbare verbetering in die toestand was, bly dit nog 'n oorsaak van bekommernis. In ons mannekragsituasie kan nie hekostig word om jare wat op die arbeidsmark gebruik kon word te verspeel nie.

Die versoeking is baie groot om uitvoerig statistiek aan te haal soos die afgelope 10 jaar baie keer in die nuus was en dit dan voor te hou as 'n baie belangrike rede waarom onderrigverbetering moet intree en onderrigont wikkeling moet geskied.

Genoemde sake is baie belangrik maar gesien in clie lig van die persentasie van dic bevolking wat tans wel die universiteit besoek sou dit ook 'n probleem oplewer indien alle studente wat by 'n universiteit inskryf sou slaag. Ons moet liewer kyk na die vermoëns en aspirasies van die studente wat wel die universiteit besoek asook na ons mannekragsituasic om tc bepaal of almal van hulle op universiteit tuishoort. Ook baie belangrik is dat na die onderrigdoelstellings van die universiteit gekyk word en die mate waarin hierdic doelstellings verwesenlik is. Die doel van toetse en eksamens is juis om doclbereiking te bepaal. Word vraestellc aan ons universiteite ontleed, soos dit op groot skaal reeds in die buiteland gedoen is, blyk dit dan van die 


\section{Die noodsaaklikheid van}

studente geweldig baic verwag word ten opsigte van die weergee van parate kennis. Kennisreproduksic geniet blykbaar hoë prioriteit in ons onderrig. Dic doel van universiteitsonderwys is egter nie dat die student net sal weet nie; daar is genoeg bronne van kennis wat geraadplecg kan word. Die doel is dat benewens kennis die student ook sal verstaan en dat hy insigte en kennis in nuwe situasies sal kan toepas, dat hy analises en sinteses sal kan doen asook waardebeoordelings op die grond van vaste uitgangspunte en kriteria. Sonder kritiese denke is die universiteit 'n oefening in uithouvermoë.

As ons waarlik 'n wetenskaplike houding deur ons onderrig by studente wil tuisbring, dit is 'n houding wat vraend, krities, vreesloos, onbevooroordeeld, gegrond op vaste uitgangspunte, en evaluerend moet wees, moet ons onderrig ook die student se wetenskaplike houding en oordeel kan oorleef. In Europa was daar 'n dekade of meer gelede studente-onluste wat in 'n mate verband gehou het met onderrigmetodes. Dit was ons tot dusver gespaar in ons land maar 'n mens vra jouself die vraag af of dit die gevolg daarvan was dat studente nie gevorm was as kritiese denkers nie en of dit beskou moet word as 'n pluimpie vir goeie onderrig aan ons universiteite.

\subsection{Finansies}

Universiteitstudie het 'n duur onderneming geword. Die totale owerheidstoelaes aan dic blanke residensiële universiteit en UNISA was in 1976 reeds 125 keer hoër as in 1918 (aangepas met die verbruikersprysindeks) terwyl die getalle selfs 60 -voudig toegeneem het. Waar die owerheid in $191857 \%$ van die koste om 'n student aan die universiteit te hou, gedra het teenoor die student se $24 \%$ blyk dit dat die staat tans reeds meer as $80 \%$ van die koste moet dra.

In die lig van die kostes verbonde aan universitêre studie is dit heeltemal natuurlik dat die gemeenskap en die staat sal kyk na dic akademiese prestasies van universitcitstudente en dan ook die gehalte van die onderrig sal bevraagteken.

Die voorgestelde subsidiëringsformule van die staat soos uiteengesit in die SANSO 110-verslag, laat duidelik blyk dat daar uitsette gemeet gaan word in plaas van koppe getel word soos wat dit in die verlede die geval was. Die universiteit sal nie net gefinansier word op die aantal studente nie maar veral op die peil van prestasie, wat betref onderwys sowel as navorsing. In die praktyk kom dit daarop neer dat nie net die inskrywingstal van die studente nie maar wel die aantal wat slaag die subsidiëring sal bepaal. Dit 


\section{S.J.P. du Plessis}

plaas groot verantwoordelikheid op die dosent wat onder druk sal verkeer om meer studente te laat slaag sonder om standaarde te verlaag. Van die dosent gaan dit groter toewyding, betrokkenheid en onderrigbekwaamheid verg. Waar die universiteit in die verlede hoolsaaklik normgerig geëvalueer het, met ander woorde die klem laat val het op die student se prestasie in vergelyking met die gemiddelde prestasie, sal die klem toenemend op kriteriumgerigte evaluering moet val. Vooraf sal baie duidelik doelwitte gestel moct word waaraan voldoen moet word om te kan slaag. Dit verg deeglike kurrikulering en veral doelwitbepaling. Word die groot lluktuasie in slaagsyfer in verskillende studicrigtings aan verskillende universiteite met mekaar vergelyk, ontstaan die vraag of standaarde verskil en of die gehalte van die onderrig in so 'n groot mate verskil.

Die linansiële toestand in ons land is tans so dat die universiteit meer sal moet doen met minder. Onderrigont wikkeling kan hier' $n$ positiewe bydrae lewer.

\subsection{Dosente}

'n Inrigting wal die grootste gedeelte van sy beskikbarc fondse aan personeelsalarisse bestec, is verplig om baic aandag aan personcelontwikkeling te gee. Tevore is verwys na die toestroming van die studente na die universiteite, maar dit moet besef word dat daar in dicselfide mate 'n toestroming van dosente na dic universiteite was, aangesien daar vir elke 12,7 studente cen dosent aangestel word (Meyer, 1982:4).

Dosentontwikkeling word bemoeilik deur verskille in moticwe, probleme en aspirasies van verskillende dosente en ook verskille in verskillende lewensstadiums van dic dosent. In dic VSA is gevind dat 'n prolessor se belangstellings met die jare verskuif vanaf die navorsingskomponent van sy opdrag na dic onderrigkomponent (Fulton \& 'Trow, 1974:54). Ervaring leer dat dit makliker is om jong dosente by onderrigontwikkelingsaksies te betrek, waarskynlik omdat die jonger dosente voel dat hulle nie prestige het om te verloor nic. Dit ten spyte van die feit dat ouer dosente ook 'n groot behoefte het asook 'n groot belangstelling in onderrigverbetering.

Baie dosente beroem hul ook op ervaring in die onderwys. 'Twintig jaar ervaring van onderrig kan twintig ervarings van diesellde ding wces. Die dosent is van mening dat hy goeic onderrig gee terwyl daar sovecl nuwe ont wikkelings was wat intussen hul opwagting gemaak het dat die onderrig in werklikheid verouderd is. Dit is vir die dosent mocilik om sy eie onderrig te 


\section{Die noodsaaklikheid van}

beoordecl indien daar nie een of ander vorm van objektiewe evalucring is nie. Hier het die instansic vir onderrigontwikkeling 'n belangrike taak.

As in gedagte gehou word dat tans meer as $70 \%$ van die dosente aan residensiële universitcite vir blankes jonger as 40 jaar is (Meyer, 1982:5) hou dit groot implikasies vir onderrigontwikkeling in. Meer as $70 \%$ van die dosente het dus meer as 25 jaar onderwys voor hulle en duisende studente sal by die cnkcle dosent nog onderrig ontvang.

\subsection{Onderrigmedia}

Ten opsigte van die onderrigmedia het daar die afgelope 2 of 3 dekades sovecl ont wikkelings plaasgevind dat onderrig nooit weer dieselfde $k$ an wees nie. Die dosent moet self geskikte onderrigmedia selekteer en hicr is bepaalde vaardighede voor nodig. Die doscnt kan ook sy eic onderrigprogramme saamstel maar dan is kundigheid nodig vir dic maak van videofilms, klankskuificprogramme, rekenaargesteunde onderrigprogramme, e.d.m.

Onderrigmedia kan onderwys meer produktief maak en studente kan vinniger leer terwyl die dosent betcr gebruik van sy tyd kan maak. Sommige onderrigmedia kan help met individualisering en studente kan tcen hulle cie tempo vorder. Sommige vorms van die media is baic geduldig en kragtig en kan die goeic dosent help om 'n nog beter dosent te word. Net sous die gocie handboek of diktaat 'n baie kragtige hulpmiddel is, so is die hele spektruin van onderrigmedia wat ook beeld en klank insluit vir die dosent van onskatbare waarde, maar dan moet hy oor die kundigheid beskik om reg daarvan gebruik te maak en hiervoor is ook opleiding nodig. By sommige van ons universitcite word soos by die skole mediasentrums ingerig. Die mediateek of selfstudiesentrum verwys na 'n ruimte wat doelbewus ingerig en tocgerus word sodat st udente met behulp van leerpakette en oudiovisuele of ander media kan studecr.

Die sckondêre rol wat nog steeds aan onderrigmedia tocgeken word blyk uit die verskynsel dat by baie van ons universiteitsbiblioteke onderrigmateriaal anders as boeke en art ikcls nie deur dic biblioteck bestuur word nie. Films, klankskuilieprogramme, strookfilms, videofilms, e.d.m. word nie sentraal beheer nie en dit is vir dosente moeilik om vas te stel wat wel beskikbaar is. Dit moet besef word dat onderrigmedia nic net onderrighulpmiddels is nie maar clat die uiteindelike doel daarvan is dat die student moet leer en dat die student dit ook tot sy beskikking moet kry wanneer hy voel dit word benodig. Dit benadruk dic noodsaaklikhcid van 'n mediateek met toegcruste studichokkies. 


\section{S.J.P. du Plessis}

Dit is egter gevaarlik om die mediasentrum en onderrigmedia in die algemeen as ' $n$ barometer van onderrigont wikkeling te beskou. As statussimbool kan onderrigmedia nie bekoslig word nie. Onderrigmedia aan 'n universitcit het docltrellende leer as doel en is nie daar vir die bevrediging van die kunssinnige skeppende lalente van sommige dosente nie. Daar moet gewaak word dat onderrigmedia nic oplossing word wat probleme sock nie. Die ellekt ticwe gebruik van onderrigmedia e is kennis daarvan en mediaseleksie en -produksic is 'n vaardigheid wat die dosent sal moct bemeester. Verkecrde mediaseleksie het in die verlede al in baie gevalle gelei tot die afskry [ van onderrigmedia as ' $n$ hulp by onderrig. Die verkeerde plek wat in die verlede aan media toegeken is blyk uit die navorsing wat daaroor gedoen is. Van voor die Tweede Wêreldoorlog af' is die radio as onderrigmedium ge-evaluecr en hicrna die televisie en tans die rekenaar. In die meeste van hicrdic ondersocke word 'n vergelyking getref tussen die kennisbemeestering met behulp van dic media tecnoor dic konvensionele manier. Van 'n sistecmbenadering waar media gebruik word waar dit die beste pas is in hicrdic cvalucrings nie van sprake nie. Dic dosent sal dus ook gelei moct word om die media in regte perspektief te sien.

\subsection{Navorsing}

As 'n maatskaplike instelling wat die opvoeding of vorming van die student onderneem, dra dic universiteit nic bloot bestaande kennis oor nie mar wel kennis wat deur dic: dosent krities ondersock is (navorsing) en wat alleen deur die student aanvaar word as gevolg van dic kritiese cvalucring daarvan. Laasgenoende is die gevolg van gocic onderrig. Dit is om hicrdie rede dat navorsing en onderrig aan die universiteit 'n onverbreekbarc cenheid vorm. Dit is die taak van die dosent om harmonie te skep in sy onderrig en navorsing sodat dic een 'n heilsame invloed op die ander het.

Ek is van mening dat onderwys dic belangrikste en primêre taak van dic universiteit is. Geen ander instansie verskaf onderwys op so 'n hoë vlak van kennis en insig nie, en dit is nie moontlik sonder navorsing nie, en om hierdie rede is navorsing noodsaaklik. Die dosent moet dus navorsing doen omdat hy op dic voorpunt van kennis moet beweeg om dit juis aan sy st udente mec te decl en te onderrig om dit self te kan doen.

Dit is egter ironies dat dosente by universiteite in dic eerste plek en in baic gevalle in die enigstc plek aangestel word vanweë hulle navorsingsvaardighede. Navorsing self het aangetoon dat daar nie 'n direkte verband tussen navorsingsproduktiwitcit en onderrigdoeltreflendluid is nie in (vgl. lig. 2). 


\section{Die noodsaaklikheid van}

Die resultate soos in die graliek uitcengesit is uit 'n twaaltal ondersocke gekies wat die beste verband tussen navorsingsproduktiwiteit en onderrigdoeltrelfendheid gec. Die verband is baie swak in hierdie geval waar die navorsing aan 'n tersiëre onderwysinrigting in dic VSA gedoen is oor 'n tydperk van 5 jaar heen.

Figuur 2:

\section{Verband: Navorsingsproduktiwiteit en onderrigdoeltreffendheid}

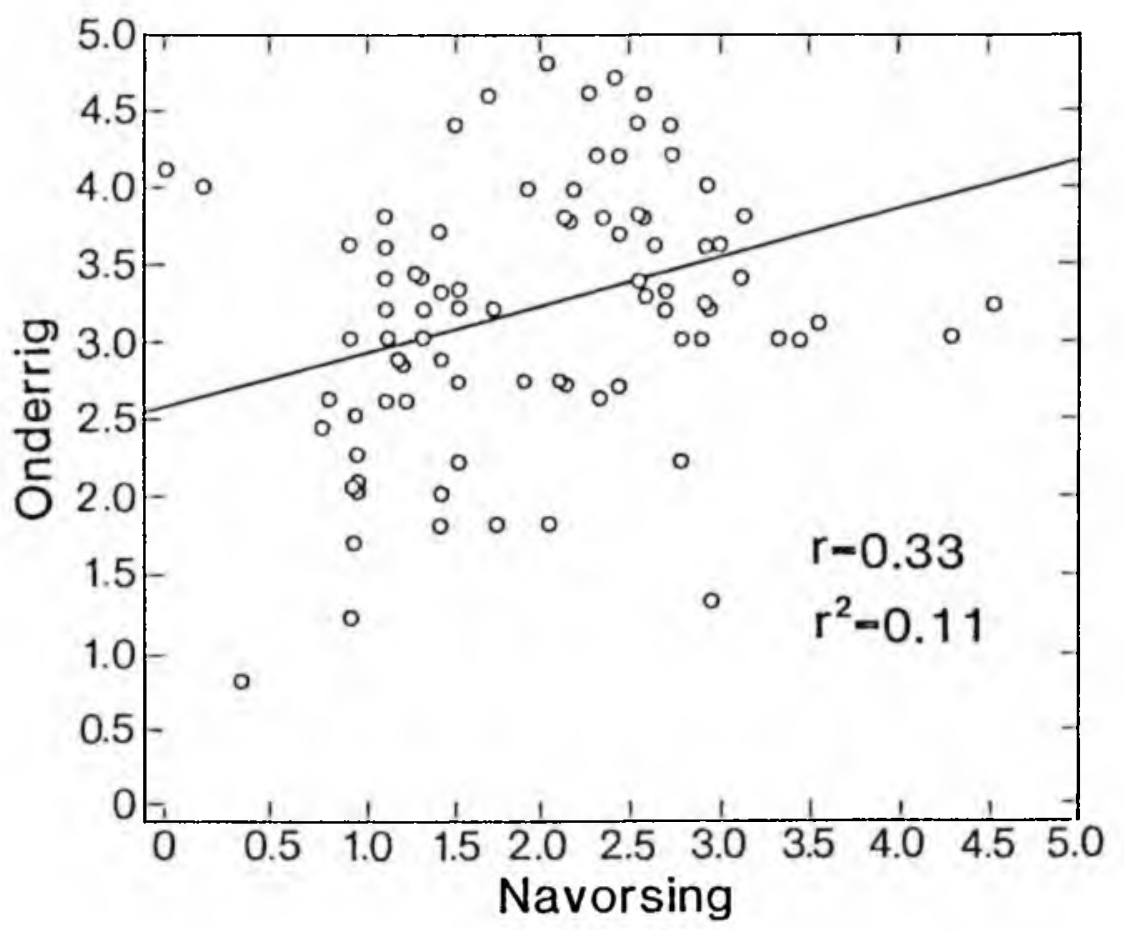

(MICHALAK \& FRIEDRICH, 1981:589).

Volgens die nuwe voorgestelde subsidieformule vir die finansiering van universitcite soos in die SANSO I 10-verslag uiteengesit, berus die subsidiëring 


\section{S.J.P. du Plessis}

sleur die staat aan universitcitc gedecltelik op dic getal artikels wat in dic geesteswetenskappe en natuurwetenskappe deur dosente gepubliseer word. Dit is verblyclend dat gepoog word om die navorsingskomponent van die dosent se taak te cvalucer. Volgens 'n navorsingsverslag van die WNNR moet dosente finansieel ondersteun word wat wel bevocgde navorsers is. Een van die hoofpilare waarop die filosolie ten opsigte van bevordering van navorsing aan dic Suid-Afrikaanse universiteite berus is om dosente aan te stel wat goeie navorsers is. Hier moet egter dadelik 'n waarskuwende woord laat hoor word. Oor dic gehalte van onderrig word min amptelik gesê. Indien die universiteite die navorsingsproduk van sy dosente wil evalucer moet die onderrig ook ge-evalueer word. Dit kan nic aanvaar word dat onderrig wel geskied en dat dic aantal periodes wat daar klas gegee word 'n aanduiding van die gehalte van die onderrig is nic.

Vakgerigte navorsing aan die universitcit moct nic oorbcklemtoon word ten kostc van die onderrigtaak van dic dosent nic.

\section{SAMEVAT'I'ING}

Dosente as groep het 'n bo-gemiddelde intelligensie, bo-gemiddelde aspirasiepeil, gespesialiscerde kennis, individualistiese persoonliklicde, groot krcatiwitcit en werksywer. Onderrig en opleiding het vandag cgter so 'n gespesialisecrde taak geword dat die dosent, ten spyte van al sy besondere vermoëns, tog hulp en voortdurende opleiding vir sy onderrigtaak norlig het. Die universiteit het vir baic lank in die RSA feitlik allecnhecrskappy gevoer ten opsigte van naskoolse opleiding. Ander tersiêre inrigtings en privaatinstansies begin steeds om meer en meer hoevvlak oplciding op 'n baie doelgerigte wyse te verskaf. Onderrigontwikkeling sal moet sorg dat dic universiteit t.o.v. dic gehalte van die onderrig sal kan saampraat.

\section{BIBLIOGRAFIE}

BEHR, A.L. 1981. University tcaching - should academics be trained? (I)W Bulletin, 2(17), 39-44, Jan.

DU 'TOI'l, 1981. Dic belangrikheid van'n mediateck (selfstudiesentrum) in universiteitsonderrig. RAU, Bulletin vir dosente, 14(2): 27-37 Okt.

ENGEL,BREC:HI', S. W. B. 1980. Dosente-ont wikkclingsprogramme aan'n tersiêre inrigting vir afst andsonderrig. Kongrespublikasic. Hoër onderwys. Navorsing en ontwikkcling. UOVS 21, 23 Jan. 1980. Blocmfontein, RSA. ERENS, G. EN LOUW, J.B.Z.. 1978. Dic statist iese feite m.b.t. die omvang van die problecm van druiping en mecr besonderlik ecrstejaarsdruiping 


\section{Die noodsaaklikheid van}

aan universiteite en lic verspreiding van druipelinge oor verskillende studiegebiede: cn vakke. (In: Dic oorgang van skool na universiteit Verrigtinge van dic Nasionale Simposium, Pretoria, 18-19 Scptember, 1980, KUH.)

ESTERIIUIZEN, W.P. 1983. Die ontwikkeling van tegnologie en die tockoms van dic universitcit. RS. 2000, 5(1):42-43.

FRY, Gerald, W. 1981. Degrecism: discase or cure. Higher liducation. 10:517-527.

FUL'TON, D cn TROW, M. 1974. Research activity in American higher education. Sociology of educalion, 47:29-73, Winter.

LEISINER, E. I982. Alrika en sy universitcite. Die Transzaler, Woensdag, 10 Januaric.

MEYER, P.S. 1982. Openingsrede. (In Dosentontwikkeling en dic praktyk. Verslag van die tweede masionale kongres van die Suid-Afrikaanse Vereniging vir navorsing en ontwikkeling in die hocr onderwys, gehou op 15-17 September tc Stellenbosch.)

MICHALAK, Stanley, J. \& FREDRICII, Robert, J. 1981. Rescarch product ivity and teaching eflect iveness at a small liberal arts college. Fournal of Higher Liducation, 52(6):578-597.

PRELLER, S.J. \& STRYDOM, A.H. 1978. Die plek, doel en rol van die universiteit in dic onderwysstelsel en meer besonderlik in die tersiêre onderwy'sstelsel - 'n Pragmatiese siening van die universiteit met die fokus op dic oorgang van skool na universitcit, KUH. Dic oorgang van skool na universitcit. Verrigtinge van die Nasionale Simposium, Pretoria, 18-19 September 1978.

SCHU'I"IE, H.J. 1979. Dic aanslag op dic universiteit. RAC-Bulletin vir Dosente, 12(1):15-25.

SL.ABBER I', B.R. 1981. Dic rol van 'n mediasentrum in onderrigontwikkeling en verbetcring. $R A(1-$ Bulletin vir Dosente, 14(3):22-26.

SIEYN, H.S. VENTIER, R.H. \& LOUW,J.B.L. 1983. Gesigspunte oor die ontwikke ling van dic universiteite tot dic jaar 2000. RSA 2000, 5(1):17-26. SIRYUOM, A.H. 1980. Die didaktick as decldissipline. Pretoria, SACUM. VAN DER MLRWE, 1980. Dic besondere onderrigtaak van die hedendaagse universiteitsdosent. (IP'-Dosent, I(1): 16-20.

VILJOLN, G. VAN N. 1983. Openingstoespraak by geleentheid van dic simposiun: 'Tendense, opleidling cn ont wikkeling van mannekrag, Vaaldriehockkampus, PU vir CiHO, 9-10.Junic. 